\title{
PERAN KOMUNIKASI SATUAN POLISI PAMONG PRAJA (SATPOL PP) DALAM MEMBERIKAN PEMBINAAN KEPADA PEDAGANG KAKI LIMA (PKL)
}

\author{
Unik Desthiani \\ Dosen Program Studi DIII Sekretari Universitas Pamulang \\ unikdesthiani@gmail.com
}

\begin{abstract}
Abstrak-Komunikasi merupakan hal penting dalam kehidupan manusia, dengan berkomunikasi manusia dapat memahami satu sama lain, mengenai keinginan, kebutuhan dan juga tujuannya. Untuk dapat memperoleh pemahaman satu sama lain dan mencapai tujuan, komunikasi harus dilakukan dengan efektif jika tidak dilakukan secara efektif, maka yang timbul adalah kesalahpahaman dan konflik. Komunikasi dapat dilakukan diberbagai lingkungan, baik itu keluarga, masyarakat maupun perusahaan. Dalam lingkungan perusahaan, komunikasi merupakan salah satu faktor penting untuk dapat mewujudkan tujuan perusahaan. Komunikasi dalam suatu perusahaan dapat terjadi antara: pemimpin dengan pemimpin, pemimpin dengan bawahan, sesama bawahan, staf perusahaan dengan pelanggan atau masyarakat. Salah satu profesi yang sangat membutuhkan komunikasi yang baik adalah Satuan Polisi Pamong Praja (Satpol PP), profesi ini berhubungan langsung dengan masyarakat luas di mana Satpol PP memiliki kewajiban untuk menegakkan peraturan pemerintah daerah, misalnya: mengenai ketertiban umum yang melarang pedagang kaki lima untuk berjualan di trotoar, untuk itu seorang Satpol PP harus dapat berkomunikasi dengan baik untuk memberikan pengertian dan pemahaman kepada Pedagang Kaki Lima agar tidak menimbulkan konflik atau kerusuhan. Penulisan ini bertujuan untuk mengetahui peran komunikasi Satpol PP dalam memberikan pembinaan kepada pedagang kaki lima.
\end{abstract}

\section{Kata kunci: Komunikasi, Satpol PP, Pembinaan Pedagang Kaki Lima}

\begin{abstract}
Communication is an important thing in human life, by communicating humans can understand each other, about their wants, needs and goals. To be able to gain understanding of one another and achieve goals, communication must be done effectively if not done effectively, then what arises is misunderstanding and conflict. Communication can be done in various environments, be it family, community or company. In the corporate environment, communication is one of the important factors in achieving company goals. Communication within a company can occur between: leader with leader, leader with subordinates, fellow subordinates, company staff with customers or the community. One of the professions that really need good communication is the Civil Service Police Unit (Satpol PP), this profession deals directly with the wider community where Satpol PP has an obligation to enforce local government regulations, for example: regarding public order which prohibits street vendors from selling on the sidewalk, for that a Satpol PP must be able to communicate well to provide understanding and understanding to street vendors so as not to cause conflict or riots. This writing aims to determine the communication role of Satpol PP in providing guidance to street vendors.
\end{abstract}

Keywords: Communication, Satpol PP, Guiding Street Vendors 


\section{PENDAHULUAN}

\section{Latar Belakang Masalah}

Dalam rangka mencari pendapatan dan penghidupan yang layak, banyak orang yang menganggap bahwa kota lah tempatnya bukan di pedesaan atau bahkan daerah terpencil, hal ini dikarenakan kota dianggap sebagai pusat kegiatan masyarakat. Anggapan ini, memberikan dampak terjadinya urbanisasi dimana semua orang dipedesaan pindah ke kota untuk mendapatkan pekerjaan yang layak. Tetapi kondisi di kota itu sendiri mengikuti modernisasi, semua pekerjaan yang semula dikerjakan oleh manusia, saat ini digantikan dengan mesin yang dianggap akan memudahkan.

Hal ini menyebabkan sempitnya lapangan pekerjaan di kota dan tentunya menimbulkan persaingan yang ketat untuk mendapatkan pekerjaan, sedangkan sebagian besar penduduk desa yang berpindah ke kota tidak memiliki keahlian yang mumpuni, sehingga mereka tidak dapat memenuhi tuntutan kerja yang ada di perkotaan. Kondisi ini menyebabkan penduduk desa yang tidak memiliki keterampilan dan pendidikan memilih untuk mengolah sektor informal untuk membiayai kehidupan mereka.

Sektor informal yang dimaksud adalah di mana mereka mencari penghasilan melalui produksi atau distribusi produk/jasa, salah satu bentuk profesinya adalah pedagang kaki lima. Mereka memilih sektor informal pun dengan berbagai keterbatasan yang dimiliki, sehingga mereka hanya memanfaatkan apa yang ada di sekitar mereka. Sebagai contoh, kegiatan distribusi yang mereka lakukan yaitu berjualan dilakukan dengan memanfaatkan lahan di kotakota besar, seperti: Jakarta, Bandung, Semarang, Yogyakarta yang peruntukan sebenernya adalah untuk lahan penghijauan.

Oleh karena itu, kehadiran PKL selalu diawasi, dan ditindak oleh Satuan Polisi Pamong Praja. Pedagang kali lima semakin menjamur di berbagai kota besar dan hal ini tidak disertai oleh adanya penyediaan lahan untuk PKL melakukan transaksi jual beli, akibatnya adalah para PKL menggunakan lahan hijau, jalan dan tempat umum untuk berjualan. Kondisi seperti ini jelas sangat mengganggu kenyamanan dan ketertiban masyarakat, trotoar yang seharusnya bisa digunakan oleh pejalan kaki jadi tidak bisa digunakan sesuai fungsi dengan adanya PKL.

Hal inilah yang menjadi tolak ukur pentingnya keberadaan aparat Satpol PP agar dapat membantu Pemerintah Daerah menegakkan Peraturan Daerah dan melaksanakan ketertiban umum, terutama dalam pembinaan untuk menumbuhkan kesadaran kepatuhan 
pedagang kaki lima (PKL) terhadap Peraturan Daerah. Untuk meningkatkan kesadaran pedagang kaki lima (PKL) dalam menjaga ketertiban dan kenyamanan di sebuah kota harus didukung oleh bagaimana Satpol PP dalam berkomunikasi dengan pedagang kaki lima (PKL) untuk menjaga ketertiban dan kenyamanan.

Dalam berkomunikasi ada beberapa hambatan terkait sumber daya, yaitu sebagai berikut:

1. Kurangnya kemampuan aparatur mengimplementasikan kebijakan, yang disebabkan oleh:

a. Pelaksana tidak inisiatif untuk mengimplementasikan kebijakan dan hanya menunggu perintah dari atas dalam bertindak;

b. Pemahaman mengenai isi kebijakan masih kurang sehingga penerapan aturan belum maksimal.

2. Selain faktor kemampuan kerja, beberapa hambatan terkait pembinaan pedagang kaki lima disebabkan oleh faktor komunikasi, yaitu:

a. Pertemuan diantara pelaksana tidak terjadi secara rutin karena kurangnya koordinasi.

b. Terdapat kesalahan persepsi dalam penyampaian informasi yang disebabkan oleh rendahnya tingkat pendidikan.

Dalam rangka mencapai komunikasi yang efektif, maka dibutuhkan pelaksanaan strategi komunikasi yang tepat. Karena komunikasi tidak hanya penyampaian suatu informasi tetapi lebih dari itu, komunikasi juga mengandung unsur-unsur persuasif sehingga orang lain mau menerima pemahaman dan pengaruh serta melakukan perintah, persuasi dan sebagainya. Berhasil atau tidaknya komunikasi tergantung pula kepada mediator yang terdapat dalam proses komunikasi atau proses penyampaian informasi. Dalam hal ini mediator yang dimaksud adalah aparat Satuan Polisi Pamong Praja. Para aparat harus dapat melakukan komunikasi dengan baik agar pesan tersampaikan dengan baik dan menghasilkan pemahaman sesuai dengan tujuan penyampaian pesan sehingga tidak menimbulkan konflik dan kesalahpahaman.

Berbagai tindakan komunikasi pada dasarnya menyesuaikan dengan konteks dimana komunikasi tersebut dilakukan, yaitu konteks komunikasi interpersonal, komunikasi intrapersonal, komunikasi kelompok, komunikasi organisasi, dan komunikasi massa. Meskipun komunikasi adalah kegiatan yang kita lakukan secara rutin dalam kehidupan sehari-hari, kenyataan menunjukkan bahwa proses komunikasi tidak selalu mudah.

Komunikasi dirasa sebagai sesuatu yang sulit karena terdapat beberapa perbedaan antar individu yang menghambat keberhasilan komunikasi, seperti: perbedaan latar belakang sosial- 
budaya, pendidikan, dan lain sebagainya. Hal inilah yang juga dirasakan oleh aparat Satpol PP dimana mereka merasa kesulitan dalam menyampaikan informasi dan memberikan pembinaan kepada PKL yang sebagaian besar memiliki tingkat pendidikan yang rendah.

Berdasarkan Latar Belakang di atas penulis bermaksud untuk menguraikan lebih lanjut mengenai "Peran Komunikasi Satuan Polisi Pamong Praja (SATPOL PP) Dalam Memberikan Pembinaan Kepada Pedagang Kaki Lima (PKL)".

\section{Identifikasi Masalah}

Berdasarkan latar belakang di atas, penulis mengidentifikasi masalah sebagai berikut:

1. Komunikasi yang dilakukan oleh aparat Satuan Polisi Pamong Praja (Satpol PP) terhadap pedagang kaki lima (PKL) masih sering menimbulkan konflik dan kesalahpahaman.

2. Ada beberapa kendala saat petugas Satpol PP melakukan pembinaan terhadap pedagang kaki lima (PKL).

\section{Perumusan Masalah}

Berdasarkan identifikasi masalah di atas, penulis merumuskan masalah sebagai berikut:

1. Bagaimana peran komunikasi Satuan Polisi Pamong Praja (Satpol PP) dalam memberikan pembinaan kepada Pedagang Kaki Lima (PKL)?

2. Kendala apa saja yang dihadapi oleh Satpol PP dalam memberikan pembinaan kepada pedagang kaki lima (PKL)?

\section{LANDASAN TEORI}

\section{Komunikasi}

\section{Definisi Komunikasi}

Definisi komunikasi dilihat berdasarkan dua aspek adalah sebagai berikut:

a. Definisi Komunikasi Secara Etimologis. Secara langsung jika etimologi atau asal kata, istilah komunikasi berasal dari bahasa latin yaitu kata komunis yang artinya sama, yaitu arti yang sama tentang sesuatu. Sebuah komunikasi terjadi ketika ada kesamaan antara orang yang terlibat dan hal-hal yang dikomunikasikan. Sebagai contoh dalam 
bentuk percakapan, komunikasi akan terjadi jika ada kesamaan makna tentang apa yang sedang diucapkan.

b. Definisi Komunikasi Secara Terminologis. Komunikasi secara terminologis berarti proses penyampaian pesan oleh seseorang kepada orang lain. Dari pengertian di atas dapat diketahui bahwa komunikasi melibatkan sejumlah orang, di mana seseorang mengekspresikan suatu pesan kepada orang lain. Dalam paradigma, komunikasi didefinisikan sebagai proses penyampaian pesan oleh seseorang kepada orang lain untuk diceritakan atau diubah opini, opini atau perilaku secara langsung atau tidak langsung melalui media.

Berdasarkan definisi tersebut, tujuan dari komunikasi adalah menginformasikan atau mengubah sikap (attitude), pendapat (opinion) dan perilaku atau (behaviour). Dalam hal pengiriman pernyataan, komunikasi bersifat paradigmatik atau informatif dan tujuan bersifat informatif dan persuasif. Komunikasi persuasif lebih sulit daripada informatif, karena tidak mudah untuk mengubah pendapat, sikap dan perilaku seseorang atau beberapa orang.

Menurut Porter dan Samovar komunikasi adalah proses yang dinamis, dilakukan melalui perilaku verbal dan non-verbal yang dikirim, diterima dan ditanggapi oleh orang lain. Alo Liliweri menyimpulkan bahwa Komunikasi melibatkan unsur-unsur dan elemen-elemen sebagai berikut:

a. Pengirim, pesan, penerima.

b. Pengirim dan penerima maksimal dua orang atau lebih.

c. Pesan berupa pikiran, ide verbal dan non verbal yang simbolis.

d. Ada pengaruh tertentu yang menghasilkan efek, dampak, tanggapan dan umpan balik.

e. Memprioritaskan hubungan antara orang (antara pribadi, pribadi, dan antar kelompok).

\section{Proses komunikasi}

Proses Komunikasi dibagi menjadi dua tahap, yaitu primer dan sekunder, yaitu:

a. Proses Komunikasi Primer atau Utama 
Merupakan proses komunikasi menggunakan simbol sebagai media utama, yaitu: bahasa, kial, sinyal gambar, warna dan seterusnya, yang bisa langsung menerjemahkan pikiran dan perasaan komunikator kepada komunikan. Bahasa banyak digunakan dalam komunikasi karena bahasa mampu menerjemahkan pikiran seseorang kepada orang lain dalam bentuk gagasan informasi atau pendapat mengenai hal-hal konkret dan abstrak tentang peristiwa yang terjadi saat ini dan di masa depan. Sedangkan kial (gesture), sinyal warna, dan gambar hanya dapat mengkomunikasikan hal-hal tertentu dan kemampuan terbatas dalam mentransmisikan seseorang memikirkan orang lain. Berdasarkan Penjelasan di atas, meskipun bahasa adalah media utama yang paling banyak digunakan dalam komunikasi, tidak semua orang pandai mencari kata-kata yang tepat dan lengkap dan dapat mencerminkan pikiran dan perasaan nyata. Selain itu kata-kata tidak harus memiliki arti yang sama untuk semua orang. Komunikasi yang efektif adalah dimana pikiran atau perasaan dapat diketahui oleh orang lain melalui penggunaan bahasa, sinyal maupun gambar.

b. Proses Komunikasi Sekunder.

Adalah proses penyampaian pesan oleh seseorang kepada orang lain dengan menggunakan alat atau fasilitas seperti surat, telepon, radio, televisi dan sebagainya. Itu karena target komunikan ada di tempat yang relatif jauh dan dalam jumlah besar. Jadi, dalam proses komunikasi, pesan disampaikan melalui media. Pentingnya peran media dalam proses ini adalah karena efisiensi mencapai sejumlah besar komunikan. Dengan menyiarkan sekali saja, sebuah pesan dapat menyebar luas ke khalayak luas. Menurut para pakar komunikasi, komunikasi media hanya efektif dan efisien dalam menyebarkan pesan informatif. Sedangkan proses menyampaikan pesan persuasif yang efektif dan efisien adalah komunikasi tatap muka. Komunikator dalam komunikasi sekunder harus mempertimbangkan karakteristik atau properti media yang akan digunakan untuk merumuskan konten pesan kepada komunikan. Berkomunikasi melalui surat kabar, radio, televisi, atau film berbeda dari komunikan dengan media telepon, surat, telegram, poster, spanduk dan seterusnya.

\section{Kendala dalam Komunikasi}


a. Hambatan sosial-antropologis

Meliputi: sosiologis, antropologis, dan hambatan psikologis. Hambatan sosioantropologis adalah hambatan proses komunikasi yang terjadi dalam konteks situasional, komunikator harus memperhatikan situasi ketika komunikasi terjadi, karena situasi sangat berpengaruh pada kelancaran komunikasi, terutama situasi yang berkaitan dengan faktor sosiologis-antropologis-psikologis. Sementara kendala sosiologis, seorang sosiolog Jerman Ferdinand Tonnies, mengklasifikasikan kehidupan manusia dalam masyarakat menjadi dua jenis asosiasi yang ia sebut gemeninchaft dan gesselchaft adalah hubungan kehidupan pribadi, statis, dan irasional, seperti dalam rumah tangga. Sedangkan Gesselchaf adalah asosiasi yang tidak personal, dinamis dan rasional, seperti asosiasi di kantor atau organisasi. Dalam situasi gemeinchaft, komunikasi tidak akan menemui banyak kendala karena bersifat pribadi sehingga bisa di lakukan dengan santai tidak seperti gesselchaft, misalnya pemimpin kepada bawahan. Jadi, berbagai kelompok dan lapisan dalam masyarakat yang menyebabkan perbedaan status sosial, agama, ideologi, tingkat pendidikan, tingkat kekayaan dan sebagainya dapat menjadi penghambat kelancaran komunikasi. Meskipun sama dalam tipenya, manusia homo sapiens berbeda dalam banyak hal, antara lain, postur tubuh, warna kulit, gaya hidup, norma, bahasa yang bisa menjadi kendala dalam komunikasi. Rintangan ini merupakan rintangan antropologis. Faktor lain yang dapat menghambat komunikasi adalah faktor psikologis. Ini karena sebelum meluncurkan komunikasi, komunikator tidak menguji komunikan sehingga komunikasi sulit untuk berhasil. Komunikan berada dalam kondisi psikologis yang tidak mungkin seperti kesedihan, kemarahan, kebingungan, perasaan kecewa, perasaan cemburu dan jika komunikan menempatkan prasangka kepada komunikator. Prasangka adalah salah satu hambatan terbesar untuk kegiatan komunikasi. Orang yang berprasangka akan menentang komunikator. Seseorang yang memiliki prasangka terhadap emosinya menyebabkan dia menarik kesimpulan tanpa menggunakan pikiran secara rasional dan tidak lagi mampu berpikir secara objektif. Prasangka sebagai faktor psikologis dapat disebabkan oleh aspek antropologis dan sosiologis yang mungkin terjadi sehubungan dengan ras, etnis, agama, partai politik, dan kelompok karena dalam pengalamannya pernah diberi kesan yang tidak baik. 
b. Hambatan Semantik

Hambatan sosiologis-antropologis psikologis ditemukan pada diri komunikan sementara penghalang semantik ditemukan di dalam diri komunikator. Hambatan ini terjadi karena bahasa yang digunakan oleh komunikator sebagai sarana untuk menyalurkan pikiran dan perasaan mereka kepada komunikan terlalu cepat, salah ketik atau karena aspek antropologis (bunyi dan tulisan yang sama tetapi memiliki arti berbeda untuk beberapa bagian) dan kata-kata tersebut mempunyai sifat konotatif. Katakata yang memiliki makna konotatif adalah kata-kata yang mengandung makna emosional dan evaluatif karena latar belakang pendidikan seseorang dan pengalaman. Untuk menghindari salah tafsir dan menjelaskan maksud sebenarnya dari menggunakan kata-kata denotatif, yang bermakna seperti yang tercantum dalam kamus dan diterima secara umum oleh kebanyakan orang yang sama dalam budaya dan bahasa.

c. Hambatan Mekanis

Hambatan mekanis dalam komunikasi berasal dari media yang digunakan. Suara telepon berisik, pengetikan kabur, suaranya hilang di pesawat radio, berita surat kabar yang sulit ditemukan di kolom koneksi, gambar yang mengular di televisi adalah semua hambatan semantik yang bisa dialami. Tetapi hal penting yang perlu diperhatikan dalam komunikasi adalah bahwa pesan komunikasi dapat diterima secara spiritual sebelum yakin dapat diterima sensorik/indrawi, dalam hal itu kata bebas dari rintangan.

\section{d. Hambatan Ekologis}

Hambatan ekologis terjadi karena gangguan lingkungan dalam proses komunikasi. Misalnya: suara orang-orang, suara bising lalu lintas, suara hujan, suara kilat, suara pesawat terbang dan lainnya. Kendala ini dapat dihindari dengan mencari tempat yang bebas dari gangguan di atas.

\section{Efektivitas Komunikasi}

Faktor kunci dalam komunikasi yang efektif adalah unsur-unsurnya atau elemenelemen komunikasi yang merupakan komunikator, komunikan, pesan dan media. Komunikator harus mengetahui audiens yang akan menjadi sasaran agar mendapatkan hasil sesuai yang diinginkan. Ia harus tampil sebagai pesan untuk memperhitungkan 
seberapa biasa target komunikan dapat mengawasi komunikator pesan. Komunikator harus mengirim pesan melalui media yang efisien dalam menjangkau target audiens, agar komunikasi menjadi efektif, proses pengkodean oleh komunikator harus dikaitkan dengan proses pengawasan oleh komunikan. Menurut Willbur Scramm pesan adalah tanda penting yang harus diketahui oleh komunikan, karena itu semakin banyak bidang pengalaman komunikator yang tumpang tindih dengan bidang pengalaman komunikan, maka akan semakin efektif pesan yang dikomunikasikan.

Agar komunikasi antara komunikan dan komunikator menjadi efektif, perlu memiliki empati, yaitu kemampuan untuk memproyeksikan diri pada orang lain. Meskipun antara komunikan dan komunikator terdapat perbedaan posisi, jenis pekerjaan, agama, etnis, ideologi, tingkat pendidikan dan lainnya jika komunikator empatik, komunikasi tidak akan gagal.

Efektivitas komunikasi tidak hanya bergantung pada unsur-unsur dalam komunikasi tetapi juga pada aspek situasi, hubungan sosial dan saling pengertian atau kebersamaan dalam makna, karena komunikasi itu sendiri adalah upaya untuk bertukar dan menegosiasikan makna, tidak hanya dari komunikator, pesan dan media atau saluran. tetapi juga peran untuk bertukar dan menegosiasikan makna antara semua pihak dan elemen dalam komunikasi untuk mencapai harmoni dan harmoni.

Faktor-faktor itu mempengaruhi efektivitas komunikasi tersebut sangat ditentukan oleh sejauh mana seseorang memiliki sikap berikut:

a. Keterbukaan, adalah sikap seseorang yang: (1) Secara objektif menilai pesan dengan menggunakan keterampilan data dan logika, (2) Bedakan dengan mudah, lihat nuansa, (3) Berorientasi pada nilai, (4) Cari informasi dari berbagai sumber, (5) Lebih profesional dan mau mengubah kepercayaan, (6) Mencari pemahaman pesan yang tidak sesuai dengan serangkaian keyakinan.

b. Perasaan Empati, Empati adalah kemampuan komunikator untuk menerima dan memahami orang lain saat dia menerima dirinya sendiri. Jadi, dia berpikir, merasakan dan bertindak terhadap dirinya sendiri.

c. Perasaan positif, yaitu perasaan seorang komunikator yang kepribadiannya, komunikan, dan situasi yang melibatkan keadaannya saling mendukung (bebas dari ancaman, bukan dikritik dan ditantang). 
d. Memberikan Dukungan. Memberikan dukungan adalah situasi dan kondisi yang dialami oleh komunikator dan komunikan yang bebas dari atmosfer ancaman, tidak dikritik dan ditantang. Sikap mendukung atau dukungan dapat mengurangi sikap defensif dalam komunikasi, orang yang defensif jika dia tidak menerima maka dia tidak menerima maka dia ada tidak jujur dan tidak empatik.

e. Mempertahankan Keseimbangan. Menjaga keseimbangan adalah situasi yang adil antara komunikator dan komunikan dalam hal kesempatan yang sama untuk berpikir, merasakan dan bertindak.

\section{Pelatihan}

Dalam UU No. 9 tahun 1995 Pasal 1 (e) menjelaskan bahwa pembinaan adalah upaya yang dilakukan oleh pemerintah, dunia bisnis, dan masyarakat melalui penyediaan bimbingan dan bantuan untuk menumbuhkan dan meningkatkan kemampuan usaha kecil untuk menjadi bisnis yang kuat dan mandiri. Dalam Peraturan Menteri Dalam Negeri Nomor 26 Tahun 2005 disebutkan definisi pelatihan adalah semua upaya dan kegiatan membimbing, mendorong, mengarahkan, memobilisasi, termasuk kegiatan koordinasi dan bimbingan teknis untuk baik, terorganisir, rapi, dan teliti sesuai dengan rencana / program implementasi dengan ketentuan, instruksi, norma, sistem, dan metode yang efektif dan efisien untuk mencapai tujuan dengan hasil yang diharapkan maksimal. Widjaya (1986) menyebutkan bahwa pembinaan adalah suatu proses/pengembangan yang mencakup urutan pemahaman yang didahului dengan membangun, menumbuhkan, dan memelihara disertai dengan upaya untuk meningkatkan, meningkatkan dan akhirnya mengembangkannya. Tujuan pembinaan agar mereka tidak inferior dan dapat bermanfaat bagi diri mereka sendiri, keluarga dan negara mereka dan negara-negara dengan modal pendidikan dan keterampilan yang diperoleh mereka dapat mandiri secara alami. Dengan demikian, pembinaan adalah segala upaya dan kegiatan memberi, mengarahkan, melatih, dan membimbing untuk mendapatkan pengetahuan dan keterampilan baru untuk mencapai tujuan dengan hasil yang diharapkan.

\section{Pedagang Kaki Lima (PKL)}

PKL adalah orang atau kelompok ekonomi lemah yang menjual kebutuhan sehari-hari, makanan atau jasa dengan modal yang relatif kecil, memiliki modal atau modal pinjaman dari pihak lain, yang menjual di tempat terlarang atau tidak. (Kartini Kartono, 1980:4). 
Kemudian menurut Yan Pieter Karafir (Soemitro, Styastie, 2002:10), menyatakan bahwa "Pedagang Kaki Lima adalah pedagang kecil yang menjual di tempat umum seperti di pinggir jalan, taman kota, toko, dan pasar tanpa izin dari pemerintah .

Dalam kamus bahasa Indonesia yang besar (1987) diterbitkan oleh Balai Pustaka menyebutkan PKL berarti:

1. Toko depan (emper) berbelanja di sisi jalan (biasanya berukuran lima kaki), digunakan sebagai tempat penjualan.

2. Tepi pinggir jalan.

Sedangkan dalam Kamus Besar Kontemporer, Peter Salim dan Yenny Salim (1991) menyebutkan trotoar yang berarti: a) Lantai beratap yang menghubungkan rumah. b) Toko Emper di sisi jalan. c) Tepi jalan. Jadi, PKL adalah pedagang yang biasanya berjualan di toko-toko (milik orang lain) atau berjualan di pinggir jalan.

\section{Satuan Polisi Pamong Praja (Satpol PP)}

Satuan Polisi Pamong Praja disingkat Satpol PP, adalah sebuah perangkat Pemerintah Daerah dalam memelihara ketentraman dan ketertiban umum serta menegakkan peraturan daerah. Satpol PP memiliki tugas-tugas berikut:

1. Menjunjung Peraturan Daerah.

2. Mengatur Ketertiban Umum.

3. Mengatur Kedamaian dan Ketentraman Publik.

4. Pelindung Masyarakat.

Dalam melakukan tugas-tugas di atas, Satuan Polisi Pamong Praja (Satpol PP) memiliki beberapa fungsi berikut ini :

1. Persiapan program dan pelaksanaan penegakan Peraturan Daerah dan Peraturan / Keputusan Walikota, pelaksanaan ketertiban umum dan perdamaian rakyat serta perlindungan masyarakat.

2. Implementasi peraturan dan regulasi daerah / Keputusan walikota.

3. Implementasi kebijakan tentang pelaksanaan ketertiban umum dan keselamatan orangorang di daerah. 
4. Pelaksanaan kebijakan perlindungan masyarakat.

5. Pelaksana koordinasi penerapan peraturan daerah dan Regulasi / Keputusan Walikota serta penyelenggaraan ketertiban umum dan kedamaian masyarakat dengan Kepolisian Republik Indonesia, penyidik, pegawai negeri dan / atau aparatur lain.

6. Pengawasan masyarakat, aparat, atau badan hukum untuk mematuhi dan mentaati penegakan Peraturan dan Regulasi Daerah / Keputusan Walikota.

7. Implementasi tugas lain yang diberikan oleh kepala daerah.

Selain memiliki tugas dan fungsi, setiap anggota Satpol PP memiliki wewenang sebagai berikut:

1. Mengambil tindakan kontrol non-yudisial terhadap anggota masyarakat, aparat atau badan hukum yang melanggar peraturan daerah atau peraturan yang dibuat oleh Walikota.

2. Bertindak melawan warga negara, aparat atau badan hukum yang mengganggu ketertiban umum dan kedamaian masyarakat.

3. Fasilitas dan pemberdayaan kapasitas untuk menjalankan perlindungan masyarakat.

4. Melakukan tindakan investigasi terhadap warga masyarakat, aparat, atau badan hukum siapa yang diduga melanggar peraturan daerah atau keputusan Walikota.

5. Melakukan tindakan administratif terhadap penduduk, komunitas, aparat, atau badan hukum yang melanggar peraturan daerah atau keputuasan Walikota.

\section{HASIL DAN PEMBAHASAN}

\section{Diskusi tentang Peran Komunikasi Unit Polisi Pegawai Negeri Sipil dalam Melakukan Bimbingan Terhadap Pedagang Kaki Lima}

Tujuan utama dari aparat Satpol PP adalah memberikan pemahaman kepada pedagang kaki lima mengenai peraturan yang terkait dengan ketertiban PKL dalam berjualan. Satpol PP memiliki peran yang penting dalam mencapai visi dan misi Badan. Peran aktif Satpol PP sangat dibutuhkan sebagai jembatan komunikasi antara pemerintah daerah dengan PKL yang berada di sepanjang jalan protokol, seperti: monas, pasar Tanah Abang. Pada bab sebelumnya, dijelaskan bahwa proses penyampaian pesan persuasif yang efektif dan efisien adalah komunikasi tatap muka, melalui komunikasi ini memungkinkan setiap peserta untuk 
menangkap reaksi orang lain secara langsung, baik secara verbal maupun non-verbal, atau melalui konseling.

Satuan Polisi Pamong Praja memilih strategi komunikasi secara langsung yaitu dengan bertatap muka untuk menyampaikan informasi dan membujuk PKL memahami dan mematuhi peraturan daerah. Penggunaan komunikasi secara langsung dianggap mudah bagi Satpol PP dalam menyampaikan informasi. Melalui tatap muka, penyampaian pesan dirasakan lebih efektif dibandingkan dengan melalui surat edaran atau selembaran.

Perbedaan tingkat pendidikan menimbulkan kendala dalam memahami isi informasi yang diberikan jika penyampaiannya hanya melalui surat edara atau selembaran. Berdasarkan pengamatan dan wawancara dengan satu anggota Unit Polisi Pamong Praja Kota Tangerang Selatan (Bapak Bahrul) mengatakan, "Dalam pendekatan dengan pedagang kaki lima tidak hanya melakukan tindakan seperti penyediaan surat peringatan, atau rapat pertemuan tetapi juga mendekati mereka secara langsung baik secara formal maupun informal, misalnya, datang langsung ke tempat penjualan", baik menggunakan seragam resmi ataupun baju biasa, sehingga pengiriman pesan dapat dilakukan dengan benar.

Menggunakan pendekatan ini secara tidak langsung dapat memperoleh banyak informasi dan ini lebih efektif. Dalam melakukan Komunikasi ini, tidak hanya sekedar berkomunikasi tetapi juga harus memiliki strategi dan metode agar proses pengiriman pesan dapat diterima dengan baik, ini sejalan dengan pengertian komunikasi, yaitu proses operasional/penyampaian berita/berita/informasi yang berarti dari satu pihak (seseorang atau tempat) ke pihak lain (seseorang atau tempat), dalam upaya untuk mendapatkan saling pengertian.

Dengan kata lain komunikasi adalah proses penyampaian pesan atau pertukaran informasi dari seseorang ke orang lain. Komunikasi verbal (komunikasi yang menggunakan kata-kata) dan non verbal (menyampaikan pesan tanpa kata-kata tetapi memberi makna pada pesan) juga memainkan peran penting di sini karena komunikasi verbal juga mencakup berbagai aspek yang mempengaruhi yaitu kosakata, kecepatan komunikasi, intonasi suara, humor, pesan singkat dan jelas dan waktu yang tepat sementara yang termasuk dalam komunikasi non verbal adalah ekspresi wajah, kontak mata, sentuhan, postur tubuh dan gaya, suara, dan gerakan. Yang dalam prosesnya semua sangat dibutuhkan, tanpa komunikasi verbal atau non 
verbal, maka dimungkinkan pencapaian suatu informasi menjadi terhambat dan tidak berjalan dengan baik, dengan kata lain terjadinya gangguan.

Berdasarkan pengamatan dan percakapan dengan seorang pedagang kaki lima dalam lima kata bahwa polisi kota sering datang untuk mengunjungi, ini berarti bahwa polisi kota memiliki fungsi dan peran mereka. Hanya saja itu dibatasi oleh PKL yang terkadang tidak mau mendengarkan. Tetapi sebenarnya masalahnya bukan hanya di sana, yang bahkan para pedagang kaki lima tidak berniat untuk selalu melanggar, tetapi karena pendidikan yang rendah dan kurangnya pengalaman kerja terkendala oleh biaya yang mahal, sehingga menyebabkan para PKL tidak dapat dihindari. dalam upayanya berjualan di pinggir jalan yang tidak membutuhkan banyak uang.

Berdasarkan hasil pengamatan dan wawancara, itu dapat disimpulkan bahwa penyampaian informasi melalui direct communication (komunikasi antarpribadi) dilakukan oleh Peralatan Satpol PP telah dilaksanakan dengan baik karena pesannya dapat sampai ke pedagang kaki lima dan komunikasi ini lebih efektif daripada hanya memberikan surat atau selebaran. Komunikasi interpersonal memiliki pengaruh besar dalam hal memengaruhi orang lain, terutama orang individu. Hal ini disebabkan, biasanya pihak-pihak yang terlibat dalam komunikasi bertemu langsung, tidak menggunakan media dalam menyampaikan pesan sehingga tidak ada jarak yang memisahkan komunikator dari komunikan (tatap muka).

Karena saling berhadapan, masing-masing pihak dapat segera mengetahui respon yang diberikan, dan mengurangi tingkat ketidakjujuran saat komunikasi terjadi.

\section{Diskusi Pembinaan Pedagang Kaki Lima}

\section{Pembinaan Pedagang Kaki Lima melalui Perpanjangan}

Pada Dinas Satuan Polisi Pamong Praja, salah satu cara dalam pembinaan adalah melalui konseling yang sebagai strategi komunikasi untuk menyampaikan informasi kepada pedagang kaki lima. Berdasarkan hasil pengamatan lapangan tentang Peran Komunikasi Interpersonal Satpol PP dalam pembinaan pedangan kaki lima diketahui bahwa aparat Satpol PP selalu mendidik pedagang tentang pengaturan jalur hijau dan pedagang kaki lima. Untuk kegiatan penyuluhan ini, telah dijadwalkan secara rutin.

Penyuluhan dan pembinaan dalam peraturan yang mengarahkan PKL agar lebih tertib dalam perdagangan, langkah-langkah tersebut dilakukan oleh petugas Satuan Polisi 
Pamong Praja dengan mengadakan rapat, rapat, mendistribusikan sirkulasi berisi peraturan daerah, dan bahkan melalui mengunjungi PKL yang secara langsung disebut sebagai komunikasi langsung /tatap muka antara Satpol PP dan PKL. Pada dasarnya PKL sudah memahami konseling yang diberikan oleh Satpol PP dan Pedagang kaki lima dapat menerima konseling dengan baik.

\section{Pembinaan Pedagang Kaki Lima melalui Sanksi}

Pada Dinas Satpol PP, pedoman dalam bentuk sanksi digunakan sebagai metode komunikasi untuk memberikan tindak lanjut bagi PKL yang melanggar peraturan daerah. Pembinan ini juga memainkan peran utama dalam memberikan efek jera pada PK. Dalam menjalankan tugasnya, Satpol PP melakukan tahap-tahap dalam membimbing dan menegakkan peraturan daerah, sedangkan jika pada tahap pertama tahap pra-emisi (informasi, himbauan, konseling, bimbingan) tidak berhasil maka dilanjutkan ke tahap kedua tahap, yaitu bimbingan melalui tindakan pencegahan (teguran lisan/tertulis). Dalam panduan ini melalui insentif, Satpol PP memberikan sanksi dalam bentuk surat peringatan kepada pedagang kaki lima yang masih melanggar peraturan yang telah disosialisasikan. Surat peringatan yang diberikan dilakukan oleh Satpol PP dua kali, jika surat peringatan ini tidak dipatuhi oleh PKL, pembongkaran baru diadakan.

Ketentuan surat peringatan ini bertujuan untuk memberikan peluang bagi pedagang kaki lima untuk melakukan perbaikan dan mengatur kembali barang dagangan mereka dengan benar, tidak menjual di trotoar dan tidak turun jalan, sehingga pedagang kaki lima dapat mandiri dalam menjaga perdamaian dan ketertiban umum bersama.

\section{Kendala yang dihadapi oleh Satpol PP dalam Pengembangan Pedagang Kaki Lima}

Dinas Satuan Polisi Pamong Praja dalam melakukan pembinaan tidak selalu berjalan dengan baik, dari hasil wawancara dan pengamatan ada beberapa kendala yang meliputi sarana dan prasarana, seperti: kendaraan yang masih kurang, ada beberapa PKL yang susah diajak bekerja sama sehingga anggota Satpol PP butuh waktu lama untuk melakukan pendekatan agar tidak terjadi kerusuhan atau konflik. 


\section{KESIMPULAN DAN SARAN}

\section{Kesimpulan}

1. Satuan Polisi Pamong Praja telah melakukan berbagai tugas dan fungsi dalam pembinaan PKL, yaitu dalam bentuk komunikasi langsung, komunikasi interpersonal (tatap muka), atau melalui konseling dan sanksi.

2. Dalam penyampaian informasi dengan berkomunikasi secara langsung, penyampaian pesan lebih efektif daripada hanya memberikan surat edaran, brosur atau plang kepada PKL.

3. Peran Satpol PP dalam membimbing atau membina melalui konseling telah berjalan dengan baik dan telah dilakukan secara rutin, hal ini dilakukan untuk memberikan informasi tambahan kepada pedagang kaki lima sehingga mereka memahami dan mengetahui daerah-daerah yang dilarang untuk dijual.

\section{Saran}

Berdasarkan hasil pengamatan, masih ada beberapa kendala yang dihadapi oleh Satpol PP dalam melakukan pembinaan PKL baik melalui penyuluhan maupun sanksi, untuk dapat mengatasi kendala tersebut yang perlu dilakukan sebagai berikut:

1. Kegiatan komunikasi langsung harus dilakukan oleh Satpol PP pada PKL, metode ini lebih efektif dibandingkan dengan menggunakan brosur atau keberadaan selebaran, karena PKL tersebut tidak semuanya berpendidikan tinggi, sehingga informasi dan pemahaman yang terbatas sangat minim.

2. Kegiatan pembinaan yang telah dilakukan oleh Satpol PP masih perlu dimaksimalkan, selain mengawasi, patroli juga harus dilakukan dengan konsisten serta perlu adanya posko Satpol PP sehingga pertumbuhan PKL yang mengganggu ketertiban dan kenyamanan dapat dicegah. Ini karena kesadaran pedagang kaki lima masih rendah, yang mengutamakan keuntungan barang dagangan yang mengabaikan ketertiban umum.

3. Pendekatan melalui dialog dengan PKL, khususnya PKL yang masih sangat sulit untuk diajak bekerjasama perlu dilaksanakan secara terus menerus, sehingga ada kesepakatan antara pemerintah kota dengan pedagang tentang lokasi yang dapat digunakan dan strategis untuk mereka berjualan. 


\section{DAFTAR PUSTAKA}

Cangara, Hafied. 2006 Pengantar Studi Komunikasi. PT. Raja Grapindo Persada, Jakarta.

Deddy Mulyana. 2005 Studi Komunikasi: Suatu Pengantar . Remaja Rosdakarya, Bandung.

Effendi, Onong Uchjana. 1990. Ilmu Komunikasi, Teori dan Praktek . PT. Remaja Rosala Karya, Bandung.

Fajar, Marhaeni. 2009 Komunikasi, Teori dan Praktek . Graha Imu, Yogyakarta.

Hasan, Erliana. 2005 Komunikasi Pemerintah . PT. Refika Aditama, Bandung.

Jalaludin Rachmat. 1994 Psikologi Komunikasi Remaja Rosdakarya, Bandung.

Muhammad, Arni. 2004 Komunikasi organisasional . Bumi Aksara, Jakarta.

Siagian, Sondang P. 2006. Manajemen Sumber Daya Manusia Bumi Aksara, Jakarta.

Thoha, Miftah. 1994 Perilaku Organisasi; Konsep dan Aplikasi Dasar . PT. Raja Grapindo Persada, Jakarta.

Thoha, Miftah. 2003 Pengembangan organisasi . Rajawali Pers, Jakarta.

\section{Artikel internet:}

http://bukharistyle.blogspot.com/2012/01/apa-pengertian-dari-pembinaandan.html. https://www.docdroid.net/wQfbWNd/prosedur-tetap-operasional-satuan-polisi-pamongpraja-kota-tangerang-selatan.pdf 